\title{
Zinc Sulphate Turbidity as a Screening Test of Passive Transfer of Immunity in Newborn Foals
}

\author{
Endrigo Pompermayer ${ }^{1}$, Flávio Desessards De La Côrte ${ }^{2,3}$ \& Mara lolanda Batistella Rubin ${ }^{3}$
}

\begin{abstract}
Background: Passive immunity acquired by colostrum ingestion is essential to prevent neonatal infections. Failure of passive transfer (FPT) of maternal immunity occurs in foals that fail to absorb enough immunoglobulins within $24 \mathrm{~h}$ after birth. Foals with FPT are at increased risk of infections and death. Serum samples from neonatal foals might be examined for FPT using the zinc sulphate turbidity (ZST) test. The aim of this study was to investigate the accuracy of the ZST test, performed at two different times after first suckling (12 and $18 \mathrm{~h}$ ), to detect FPT in newborn foals. The effect of temperature on the turbidity intensity resulting from the ZST reaction was also investigated.

Materials, Methods \& Results: Blood samples were collected from 112 newborn foals at $12 \mathrm{~h}$ after the first colostrum intake. In 36 foals, additional serum samples were collected at $18 \mathrm{~h}$ after first colostrum intake. The serum samples were tested with the ZST test and, later, in the laboratory setting, the ZST test was repeated. The IgG levels were measured by single radial immunodiffusion (SRID), which was used as the reference method. The standard solution used for the interpretation of results had a turbidity corresponding to approximately $800 \mathrm{mg} / \mathrm{dL}$ of immunoglobulins (IgG). The mean $\operatorname{IgG}$ concentration measured at 12 and $18 \mathrm{~h}$ after the first colostrum intake was analyzed using the t-test for paired samples. Values of absorbance of ZST test under different temperatures were analyzed using a one-way analysis of variance, and means were compared using the Tukey test. The relationship between the temperature of the solution and absorbance was determined using the Pearson's correlation coefficient. Based on SRID results, 12 foals (10.7\%) had serum IgG concentration $<400 \mathrm{mg}$ and 26 foals $(23.2 \%)$ had IgG levels between 400 and $800 \mathrm{mg} / \mathrm{dL}$. Serum levels of IgG determined by SRID in 36 foals were similar $(P>0.05)$ between $12 \mathrm{~h}(943.9 \pm 508.6 \mathrm{mg} / \mathrm{dL})$ and $18 \mathrm{~h}(975.9 \pm 525.6 \mathrm{mg} / \mathrm{dL})$ after the first colostrum intake. The sensitivity values were $76.3 \%$ and $71.0 \%(P>0.05)$ for tests performed at farm and laboratory, respectively. The specificity was higher $(P<0.05)$ for ZST tests performed at laboratory $(94.6 \%)$ than at farms $(73.0 \%)$. Twenty-nine of the 38 foals $(76.3 \%)$ with $\operatorname{IgG}<800 \mathrm{mg} / \mathrm{dL}$ were correctly detected using the ZST test at farms. There was a strong correlation $(\mathrm{r}=0.92 ; P<0.0001)$ between the temperature of the solution test and the degree of turbidity. The absorbance after the reaction of serum with zinc sulphate was similar between the temperatures of 30,34 and $37^{\circ} \mathrm{C}$, which had higher values than 20 and $25^{\circ} \mathrm{C}$.

Discussion: The ZST test can be performed at $12 \mathrm{~h}$ after the first suckling. The lower specificity of tests run at farms compared to laboratory resulted in more foals with false positive diagnosis. The main cause of false positives at farms was probably the low temperature of the zinc sulphate solution at the time of testing, delaying the reaction and underestimating the IgG concentration. This assumption was reinforced by the increased specificity observed when the test was repeated with the same serum samples under controlled temperature of a laboratory. Additionally, the positive correlation observed between the temperature and degree of turbidity confirms that the reaction is temperature dependent. In the Southern hemisphere, most Thoroughbred foals are born during winter, when room temperature is far below the ideal temperature for good performance of the ZST test. Therefore, the number of false positives will likely be reduced if tests are performed at the farms under adequate temperature of solution (between 30 and $37^{\circ} \mathrm{C}$ ). This will reduce the number of foals receiving unnecessary treatment.
\end{abstract}

Keywords: equine, IgG, immunoglobulin, colostrum, ZST, passive immunity. 


\section{INTRODUCTION}

Although newborn foals are immunocompetent, the regulation of immunity and responses to pathogens or vaccination are markedly different between foals and adult horses [22,32,33]. The immaturity of the immune system determine that foals must acquire protection against environmental opportunistic pathogens by colostrum ingestion $[19,20]$.

The serum $\operatorname{IgG}$ concentration required for adequate protection of foals is still controversial, but IgG levels below $400 \mathrm{mg} / \mathrm{dL}$ usually characterize a failure of passive transfer (FPT), whereas partial FPT is defined at concentrations between 400 and $800 \mathrm{mg} /$ $\mathrm{dL}$ [9]. The measurement of IgG in foals older than $12 \mathrm{~h}$ of age provides an indication of the efficacy of passive transfer of colostral immunity [1], but the best moment to determine the immune status of foals is not well defined. The occurrence of FPT has been diagnosed at different times within $24 \mathrm{~h}$ after birth $[5,6,17]$ or even later [21,34].

The zinc sulphate turbidity (ZST) test is a simple, rapid, indirect and subjective method that can be used to estimate the immune status of foals $[6,11,17,28]$. Although it has been routinely used in many farms in Southern Brazil, the time for blood collection after birth and the temperature to perform the test may vary under field conditions.

The aim of this study was to evaluate the reliability of the ZST test performed at two different times after first suckling (12 and $18 \mathrm{~h}$ ), at farm and laboratory conditions, as an early diagnostic tool to detect FPT in newborn foals, using the single radial immunodiffusion as the reference method. An additional objective was to test the hypothesis that temperature might be a crucial factor in performing a ZST.

\section{MATERIALS AND METHODS}

Blood samples were collected from 112 newborn Thoroughbred foals, belonging to eight farms in the Rio Grande do Sul State, Southern Brazil, where the ZST test has been routinely used in these farms.

\section{Zinc sulphate and barium sulphate solutions}

Procedures used previously $[29,30]$ provided the basis to prepare the ZST test solution and the standard solution (barium sulphate), except for the use of soda lime. The solution-test of zinc sulphate $\left(\mathrm{ZnSO}_{4} \cdot 7 \mathrm{H} 2 \mathrm{O}\right)^{1}$ was prepared with $208 \mathrm{~g}$ in $1 \mathrm{~L}$ of ultra-pure water (Milli-
Q) $)^{2}$, previously boiled for $10 \mathrm{~min}$. This boiled water was immediately transferred into a glass vial containing zinc sulphate and agitated. When the solution reached the room temperature, $6 \mathrm{~mL}$ were pipetted into $10 \mathrm{~mL}$ vacutainer red-top blood collection glass tubes ${ }^{3}$. Each tube had the carbon dioxide aspirated from the inside using a syringe and needle, immediately after pipetting the solution-test. The tubes were stored at room temperature protected from light in a paper closed box until their use.

The standard solution was prepared with 94 $\mathrm{mL}$ of $0.2 \mathrm{~N}$ sulfuric acid (95-97\%) $)^{4}$ and $6 \mathrm{~mL}$ of 1.15 $\mathrm{g} / 100 \mathrm{~mL}$ barium chloride $(\mathrm{BaCl} 2.2 \mathrm{H} 2 \mathrm{O})^{1}$ solution in order to obtain 40 units of turbidity by UV 1800 spectrophotometric measure ${ }^{5}$ at $420 \mathrm{~nm}$ wavelength, corresponding to approximately $800 \mathrm{mg} / \mathrm{dL}$ of IgG.

\section{Farm testing}

At all eight farms, $8 \mathrm{~mL}$ of blood was collected from the jugular vein, $12 \mathrm{~h}(\mathrm{n}=112)$, and at two of those farms blood collection was again performed at $18 \mathrm{~h}(\mathrm{n}=36)$ after the first colostrum intake. The serum was obtained after clot retraction, and the immunoglobulin content was assessed using a ZST test. At farms, the tubes containing the solution for the ZST test were kept at room temperature, which varied between -1.2 and $32.3^{\circ} \mathrm{C}$ during the breeding season (July through November). The remaining serum was frozen at $-20^{\circ} \mathrm{C}$ for further quantification of serum $\mathrm{IgG}$ and reassessment of the ZST test in the laboratory environment. These samples remained cryopreserved for up to seven months. Hemolyzed serum samples were not included in the present study.

After clot retraction, $0.1 \mathrm{~mL}$ of serum was added to tubes containing $6 \mathrm{~mL}$ of the zinc sulphate solution 1 and agitated. The reading of the ZST was performed within 15-60 s. The turbidity of the solution ZST + serum was visually compared to a standard solution of barium sulphate.

To diagnose the immune status of the foals the results were distributed into two groups according to the turbidity intensity of the ZST test. A turbidity below the standard was considered as the foal having an inadequate transfer of immunity, whereas a turbidity intensity equal to or greater than the standard was considered as adequate immunity transfer.

\section{Laboratory testing}

The ZST test was repeated at the laboratory with the zinc sulphate solution at $37^{\circ} \mathrm{C}$. The absorbance 
(turbidity) was read in the spectrophotometer (at 420 $\mathrm{nm})$ within 15-60 s. The IgG content (mg/dL) of each thawed serum sample was measured by single radial immunodiffusion - (Equine IgG RID Kit) SRID ${ }^{6}$, as indicated by the manufacturer, and this was considered the reference method $[10,30]$.

\section{Temperature assays}

In order to determine which temperature was the most adequate to perform the test, 200 ZST tubes were tested using the same serum samples incubated at different temperatures of the test solution (20, 25, 30,34 and $37^{\circ} \mathrm{C}$ ) and repeated three times by three independent evaluators, using 3 different batches of ZST solution.

\section{Statistical analysis}

A ZST test presenting turbidity below the barium sulphate standard was considered as a positive test, denoting the occurrence of FPT. The turbidity equal or more intense than the standard was considered as a negative test, with no occurrence of FPT. Foals with FPT and tested positive were the true positives (TP). Foals with FPT and tested negative were the false negatives (FN). Foals without FPT and tested positive were the false positives (FP). Foals without FPT and tested negative were the true negatives. The sensitivity was referred to as the ability of the ZST test to correctly identify those foals with FPT and was calculated dividing TP by $(\mathrm{TP}+\mathrm{FN})$. The specificity was referred to as the ability of the ZST test to correctly identify those foals without FPT and was calculated dividing $\mathrm{TN}$ by $(\mathrm{FP}+\mathrm{TN})$. The positive predictive value was defined as the probability of a foal with a positive ZST result truly had FPT and was calculated dividing TP by (TP + FP). The negative predictive value was defined as the probability of a foal with a negative ZST result truly had an adequate passive transfer of immunity. It was calculated dividing $\mathrm{TN}$ by $(\mathrm{TN}+\mathrm{FN})$. The accuracy was considered as the probability of correctly detecting foals with an adequate level of passive immune transfer or with FPT. The accuracy was calculated dividing $(\mathrm{TP}+\mathrm{TN})$ by $(\mathrm{TP}+\mathrm{TN}+\mathrm{FP}+\mathrm{FN})$.

The mean $\mathrm{IgG}$ concentration, measured at 12 and $18 \mathrm{~h}$ after the first colostrum intake, was analyzed using the t-test for paired samples. Absorbance values of the ZST test performed under different temperatures were analyzed through a one-way analysis of variance and means were compared using the Tukey test. The Pearson's correlation coefficient was calculated to determine the relationship between the temperature and absorbance after the reaction of serum with the zinc sulphate solution. The McNemar test for paired proportions was used to compare sensitivity, specificity and accuracy [6] between Farm and Laboratory, and between 12 and $18 \mathrm{~h}$ within Farm or Laboratory. The kappa coefficient was calculated to verify the agreement in the results of ZST test for the same serum samples between Farm and Laboratory. The level of significance was set at $\mathrm{P}<0.05$.

\section{RESULTS}

Based on SRID test of samples collected at $12 \mathrm{~h}$ from 112 foals, the mean IgG concentration was $1270.8 \pm 872.9 \mathrm{mg} / \mathrm{dL}$, and 38 foals (33.9\%) had $\mathrm{IgG}$ concentration $<800 \mathrm{mg} / \mathrm{dL}$. Considering the usual definition of partial FPT $(800>\mathrm{IgG} \geq 400 \mathrm{mg} / \mathrm{dL})$ and total FPT (IgG < 400mg/dL), 26 foals $(23.2 \%)$ and 12 foals $(10.7 \%)$ were respectively affected.

Serum levels of IgG determined by SRID in 36 foals were similar $(\mathrm{P}>0.05)$ between $12 \mathrm{~h}(943.9$ $\pm 508.6 \mathrm{mg} / \mathrm{dL})$ and $18 \mathrm{~h}(975.9 \pm 525.6 \mathrm{mg} / \mathrm{dL})$ after the first colostrum intake. The accuracy, sensitivity and specificity were similar between tests performed at 12 and $18 \mathrm{~h}$, in both farm and laboratory conditions (Table 1). The performance of ZST test was identical between 12 and $18 \mathrm{~h}$ for $30(83.3 \%$; 30/36) and 29 $(80.6 \%$; 29/36) samples tested at farm and laboratory, respectively. Among the discrepant results, 3 foals had the IgG concentration changed at $18 \mathrm{~h}$ to a level that justified a different diagnosis from that performed at $12 \mathrm{~h}$.

The ZST interpretation was identical between farm and laboratory assays for 80 samples $(71.4 \%$; $80 / 112$ ), with a fair agreement (Kappa coefficient $=$ $0.39 \pm 0.08$; confidence interval $=0.23-0.56)$. The performance of ZST test with serum samples collected at $12 \mathrm{~h}$ from 112 foals is shown in Table 2. The accuracy and specificity increased significantly $(P<0.05)$ in tests performed at laboratory compared to those performed at farms (Table 2). Twenty foals were mistakenly considered as affected by FPT (false positive) despite their IgG $>800 \mathrm{mg} / \mathrm{dL}$ (Figure 1) when the ZST test was run at farms. There were 9 and 11 foals classified as normal, at farm and laboratory, 


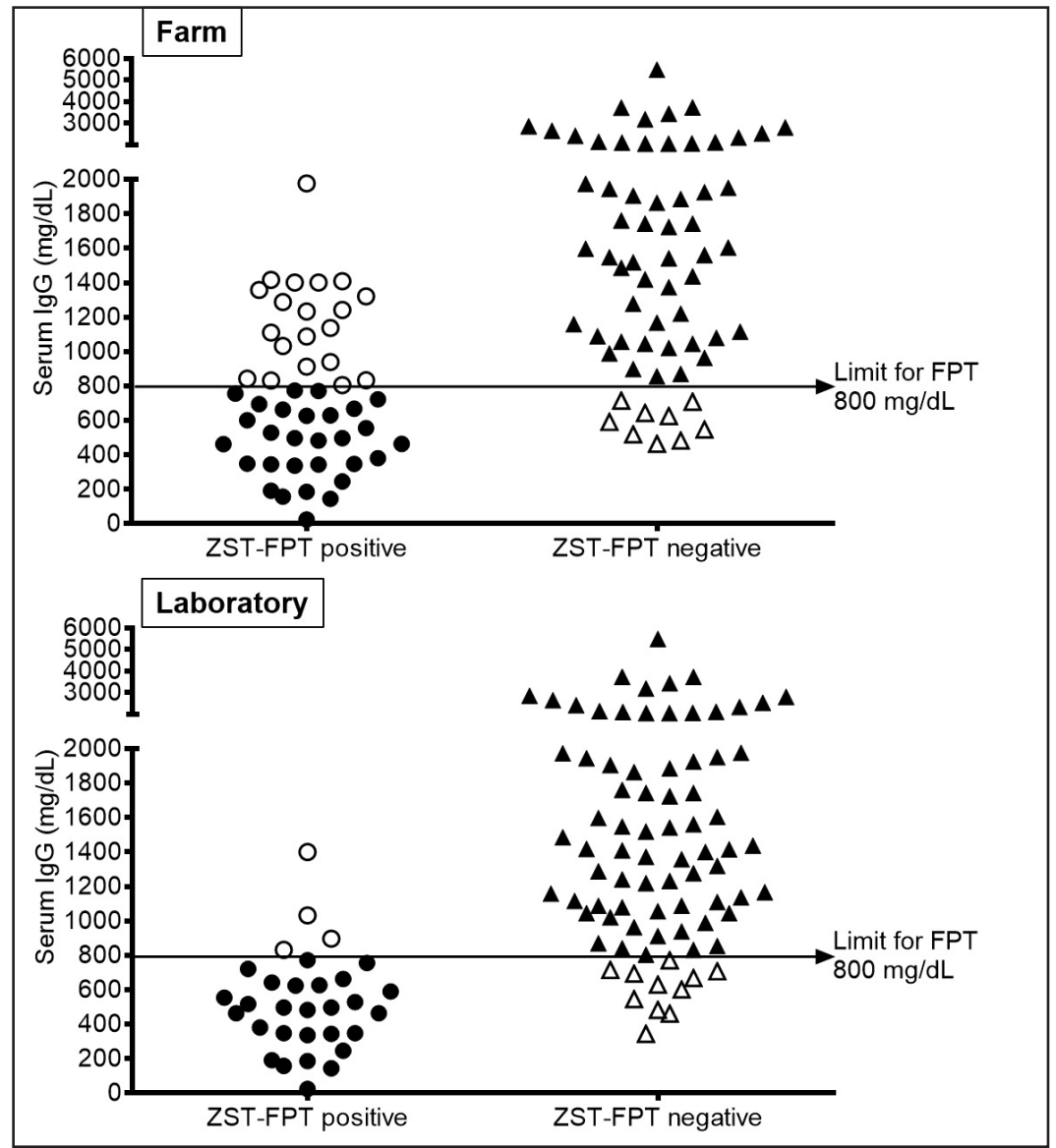

Figure 1. Identification of failure of passive (FPT) using the zinc sulphate turbidity (ZST) test and $\mathrm{IgG}$ concentration measured by single radial immunodiffusion. Serum samples were obtained from 112 foals at $12 \mathrm{~h}$ after first suckling and tested at farm and laboratory. ZST-FPT positive: foals visually classified as hypogammaglobulinaemic $(<800 \mathrm{mg} / \mathrm{dL}$; circles; open circles - false FPT positive); ZST-FPT negative: foals visually classified as normoglobulinaemic ( $\geq 800 \mathrm{mg}$ / dL; triangles; open triangles - false FPT negative).

Table 1. Performance of the Zinc Sulphate Turbidity test to diagnose the failure of passive transfer using the Single Radial Immunodiffusion (cut-off point: $<800 \mathrm{mg} / \mathrm{dL}$ of $\mathrm{IgG}$ ) as the reference method, in 36 neonatal foals from two Thoroughbred farms.

\begin{tabular}{ccccc}
\hline \multirow{2}{*}{ Variable } & \multicolumn{2}{c}{ Farm } & \multicolumn{2}{c}{ Laboratory } \\
\cline { 2 - 5 } & $12 \mathrm{~h}$ & $18 \mathrm{~h}$ & $12 \mathrm{~h}$ & $18 \mathrm{~h}$ \\
\hline True positive & 15 & 11 & 13 & 14 \\
True negative & 16 & 17 & 18 & 19 \\
False positive & 3 & 3 & 1 & 1 \\
False negative & 2 & 5 & 4 & 2 \\
Accuracy,$\%$ & 86.1 & 77.8 & 86.1 & 91.7 \\
& $(70.9-94.4)$ & $(61.7-88.5)$ & $(70.9-94.4)$ & $(77.4-97.9)$ \\
Sensitivity\#, \% & 88.2 & 68.7 & 76.5 & 87.5 \\
& $(64.4-98.0)$ & $(44.1-86.1)$ & $(52.2-90.9)$ & $(62.7-97.8)$ \\
Specificity\#, \% & 84.2 & 85.0 & 94.7 & 95.0 \\
& $(61.6-95.3)$ & $(63.1-95.6)$ & $(74.0-99.9)$ & $(75.1-99.9)$ \\
Positive predictive value, \% & 83.3 & 78.6 & 92.9 & 93.3 \\
& $(59.5-95.0)$ & $(51.7-93.2)$ & $(66.1-99.8)$ & $(68.0-99.8)$ \\
Negative predictive value, \% & 88.9 & 77.3 & 81.8 & 90.5 \\
& $(65.9-98.1)$ & $(56.1-90.3)$ & $(60.9-93.3)$ & $(69.9-98.6)$ \\
\hline
\end{tabular}

The same samples were tested at both farm and laboratory. The 95\% confidence intervals are shown within parentheses. "The accuracy, sensitivity and specificity were compared between 12 and $18 \mathrm{~h}$, within Farm and Laboratory, using the McNemar test for paired proportions. These variables were not different between 12 and $18 \mathrm{~h}(P>0.05)$. 
Table 2. Performance of the Zinc Sulphate Turbidity test to diagnose the failure of passive transfer using Single Radial Immunodiffusion as the reference method (cut-off point: $<800 \mathrm{mg} / \mathrm{dL}$ of $\mathrm{IgG}$ ), in serum samples collected at $12 \mathrm{~h}$ after first suckling from 112 foals from eight Thoroughbred farms.

\begin{tabular}{|c|c|c|}
\hline Variable & Farm & Laboratory \\
\hline True positive & 29 & 27 \\
\hline True negative & 54 & 70 \\
\hline False positive & 20 & 4 \\
\hline False negative & 9 & 11 \\
\hline Accuracy $\#, \%$ & $74.1(65.2-81.4)^{\mathrm{a}}$ & $86.6(79.0-91.8)^{\mathrm{b}}$ \\
\hline Sensitivity ${ }^{\#}, \%$ & $76.3(60.6-87.2)^{\mathrm{a}}$ & $71.0(55.1-83.1)^{\mathrm{a}}$ \\
\hline Specificity\#, \% & $73.0(61.8-81.8)^{\mathrm{a}}$ & $94.6(86.5-98.3)^{b}$ \\
\hline Positive predictive value, $\%$ & $59.2(45.2-71.8)$ & $87.1(70.5-95.5)$ \\
\hline Negative predictive value, $\%$ & $85.7(74.8-92.5)$ & $86.4(77.1-92.4)$ \\
\hline
\end{tabular}

respectively, even though they had $\mathrm{IgG}<800 \mathrm{mg} / \mathrm{dL}$ (Figure 1).

There was a strong correlation $(\mathrm{r}=0.92 ; P<$ $0.0001)$ between the temperature and turbidity of the zinc sulphate solution after reacting with serum. The absorbance was similar among temperatures of 30, 34 and $37^{\circ} \mathrm{C}$, which had higher values than 20 and $25^{\circ} \mathrm{C}$. Mean absorbance values were $1.62( \pm 0.178), 1.83( \pm 0.084)$, $2.10( \pm 0.041), 2.17( \pm 0.014)$, and $2.20( \pm 0.039)$ for the temperatures of $20,25,30,34$ and $37^{\circ} \mathrm{C}$, respectively.

\section{DISCUSSION}

Total FPT $(10.7 \%)$ defined at $\mathrm{IgG}<400 \mathrm{mg} / \mathrm{dL}$ is in accordance to previous findings of FPT varying between $2.9 \%$ and $27 \%[4,6,7,17,21,34]$. The cut-off of $<800 \mathrm{mg} / \mathrm{dL}$ was used in ZST tests run in the present study and the incidence of FPT was $33.9 \%$ (38/112), which is within the range of 9.6 to $42 \%$ observed in clinically normal or hospitalized foals when this same cut-off point was used $[6,12,23]$.

There are numerous direct or indirect methods, others than the ZST test, available to measure serum IgG in the foal: SRID, glutaraldehyde coagulation test, latex agglutination test, enzyme immunoassay, electrophoresis, determination of total protein content, turbidimetric immunoassay and infrared spectrometry $[2,3,5,13,25,26]$. The SRID allows direct, objective and individual determination of immunoglobulins and is considered the reference method for serum immunoglobulin determination. It requires, however, a prolonged laboratory processing time (18 to $24 \mathrm{~h}$ ), retarding the treatment of foals with FPT $[10,29,30,35]$.
The ZST test is easy to use under field conditions, is relatively inexpensive and fast. Nevertheless, a decreased performance of ZST test compared with the reference method or other less subjective screening tests has been reported $[6,28]$. Its accuracy is reduced due to its subjective nature of interpretation and the dependence of results on several factors, such as time, temperature, amount of dissolved carbon dioxide and $\mathrm{pH}$ of the reaction mixture [18,27].

The specificity of the ZST test run at farms $(73.0 \%)$ is comparable or slightly higher than reported in other studies (56.9-72.2\%), when the cut-off used for determining FPT was $<800 \mathrm{mg} / \mathrm{dL}[6,28]$. The greater occurrence of false positives corroborates reports of reduced specificity and unnecessary treatment of foals with adequate $\mathrm{IgG}$ concentration [6]. In the present study, more foals (20 versus 4 foals in ZST tests run at farms and laboratory, respectively) were submitted to treatment at farms because they were considered as having FPT regardless of their adequate immune status. Although the treatment of foals with no FPT does not compromise their immune status, unnecessary treatment in foals with false positive ZST tests can lead to stress due to the restraint of the foal, time consuming and economic loss with costs mainly if plasma transfusion is used. If the treatment is an intravenous administration of plasma, a liter of good quality transfused plasma can result in an increase of 200-400 mg/dL in serum IgG level [31]. However, the plasma transfusion may also cause adverse reactions, such as tachycardia, tachypnea, shivering, restlessness, the development of urticarial wheals or eye/muzzle edema, and coughing [31]. Considering that colostrum generally has 
much higher immunoglobulin levels than plasma [7], its use for immunoglobulin replacement is preferred because it reduces the stress suffered by the foal, increases the efficiency of treatment and reduces the costs. In farms of the present study the treatment of foals with FPT is usually performed by oral supplementation of frozen-thawed banked colostrum. When FPT is suspected or diagnosed in a foal less than 12 to $16 \mathrm{~h}$ old, oral supplementation with frozen-thawed colostrum still may effectively raise the serum immunoglobulin concentration to protective levels [31]. Although the efficiency of IgG absorption was $51.6 \%$ within $12 \mathrm{~h}$, the delayed administration of colostrum (12-18 $\mathrm{h}$ postpartum) to foals prevented from sucking the mare for $12 \mathrm{~h}$ resulted in the absorption of approximately $28 \%$ of ingested IgG. However, these foals subsequently demonstrated mean circulating $\operatorname{IgG}$ concentration close to $700 \mathrm{mg} / \mathrm{dL}$, which was considered adequate for healthy foals in well-managed environments [24]. Colostrum provided $24 \mathrm{~h}$ after birth has proved to be still effective in raising the serum IgG levels in $90 \%$ of treated foals [8]. Most foals of light horse breeds should consume 1 to $2 \mathrm{~L}$ of normal colostrum, administered as serial feedings of 250 to $500 \mathrm{~mL}$ [31]. Whenever the foal has been given colostrum, it should be closely monitored because it might develop isoerythrolysis.

The main cause of false positives observed at farms was probably the low temperature of the zinc sulphate solution at the time of testing. This assumption was reinforced by the increased specificity (94.6\%) when the test was repeated with the same serum samples under controlled temperature of laboratory. Additionally, the positive correlation observed between the temperature and degree of turbidity shows that the reaction is temperature dependent. The low temperature of the test solution probably delayed the reaction, which is proved to be time and temperature dependent in ZST tests performed with neonatal calf serum [18]. In the Southern hemisphere, most Thoroughbred foals are born during winter (July-August), when room temperature is far below the ideal temperature for good performance of the test. Therefore, to provide more accurate results, the test solution should be warmed in a water bath at a temperature of $30-37^{\circ} \mathrm{C}$.

Nine and 11 foals had a false negative result, at farm and laboratory, respectively, and would not be treated even if they had $\operatorname{IgG}<800 \mathrm{mg} / \mathrm{mL}$. However, it is important to mention that despite their negative result in ZST test, only one of these foals had IgG concentra- tion below $400 \mathrm{mg} / \mathrm{dL}$ when tested at the laboratory. The other foals had IgG levels between 462 and 771 $\mathrm{mg} / \mathrm{dL}$, indicating that they had partial FPT. Less foals with partial FPT have infections requiring therapy than those having total FPT [19], and corrective measures should be taken mainly when the IgG concentration is below the critical level of $400 \mathrm{mg} / \mathrm{dL}$ [17]. Clinically normal foals with no apparent risk factors for sepsis and IgG concentrations between 400 and $800 \mathrm{mg} / \mathrm{dL}$ may not require treatment if they are housed in a clean environment [9]. Health status of foals with compromised passive transfer depends heavily on the environmental factors. Foals kept in bad conditions of stall cleanness, handling, crowded stables or dusty paddocks are prone to get sick and spread contagious diseases [16,29].

The occurrence of false negatives could not be attributed to a long time of incubation because the turbidity reading was conducted within 15 to 60 $\mathrm{s}$ after mixing the serum with the zinc sulphate solution. Although the turbidity can be interpreted after 1 $\mathrm{h}[6,11,21,26]$, a long incubation time make the ZST test less convenient to use than other tests. The time of 15 to $60 \mathrm{~s}$ was already successfully used, and errors in overestimating $\operatorname{IgG}$ were lower when samples were incubated for $15 \mathrm{~s}$ versus $60 \mathrm{~min}$, probably because globulin precipitation apart from immunoglobulins occurs with longer incubation time [17]. The presence of hemolysis may also result in overestimation of $\mathrm{IgG}$ concentration $[16,26]$, hence increasing the number of false negatives. However, this event could not explain the occurrence of false negatives because hemolyzed serum samples were not included in the present study.

The similar IgG levels observed between 12 and $18 \mathrm{~h}$ after colostrum intake agrees with stable $\mathrm{IgG}$ levels from $12 \mathrm{~h}$ onward [15] and with the highest IgG concentration being reached at 13-16 $\mathrm{h}$ postnatum [7]. The number of false positives were not altered, and a small discrepancy was observed in the number of false negatives between 12 and $18 \mathrm{~h}$. Taken together, these results showed that the ZST test can be performed at $12 \mathrm{~h}$ after the first suckling. A serum IgG concentration $>800 \mathrm{mg} / \mathrm{dL}$ is acquired by $42.8 \%$ of the newborn foals within $8 \mathrm{~h}$ after birth [14], but by $9 \mathrm{~h}$ all the foals reach concentrations $>800 \mathrm{mg} / \mathrm{dL}$ [10]. Therefore, $8 \mathrm{~h}$ after birth is too early for determining the IgG concentration. However, if the immune status is determined between 8 and $12 \mathrm{~h}$ would give the foal time to absorb immunoglobulins, but would also allow enough time 
for the veterinarian correct a partial or a complete FPT with oral supplementation of colostrum [1,2,10,16,17].

\section{CONCLUSIONS}

The ZST test can be performed at $12 \mathrm{~h}$ after the first suckling, although moderate specificity and sensitivity were observed in tests performed at farms under the conditions of this study. Results of the ZST test are less reliable at temperatures below $30^{\circ} \mathrm{C}$, and the number of false positives will likely be reduced if tests are performed at farms under adequate temperature of solution (between 30 and $37^{\circ} \mathrm{C}$ ). This will reduce the number of foals receiving unnecessary treatment.

\section{MANUFACTURERS}

${ }^{1}$ Sigma Aldrich Co. St. Louis, MO, USA.

${ }^{2}$ Millipore S.A.S. Molsheim, Bas-Rhin, France.

${ }^{3}$ Beckton, Dickinson. Juiz de Fora, MG. Brazil.

${ }^{4}$ Merck Merck KGaA. Darmstadt, Germany.

${ }^{5}$ Shimadzu Corporation. Kyoto, Japan.
${ }^{6}$ VMRD Inc. Pullman, WA, USA.

Funding. Extension project from Laboratório de Embriologia Animal/UFSM (066/2008), Santa Maria, RS, Brazil.

Acknowledgements. The authors thank to the veterinarians whose cooperation is deeply appreciated: Alex B. G. Menezes, Aline R. Vivian, Carlos H. B. Borges, Emílio V. C. de Borba, Friedrich Frey Jr., Gabriele B. da Silva, Graziela T. Cescon, Luisa L. Silveira, Marcio C. Stanicki, Miguel Gallio, Paulo N. L. Bergamo, Raul H. G. da Rocha, Roberta C. F. Pereira, Roberto V. da Silveira, Rogério Ferreira, Sabine Kasinger, Vanessa M. Brucker and Ulisses L. Carneiro. We are extremely grateful to Prof. MV, MSc. PhD Mari Lourdes Bernardi for her valuable work revising the statistical analysis as well as improvements in writing this manuscript.

Ethical approval. This study was approved by the Ethics and Animal Experimentation Committee of the Federal University of Santa Maria, case number 81/2009.

Declaration of interest. The authors declare no conflict of interest. The authors alone are responsible for the content and writing of paper.

\section{REFERENCES}

1 Axon J.E. \& Palmer J.E. 2008. Clinical pathology of the foal. Veterinary Clinics Equine Practice. 24: 357-385.

2 Baird A.N., Pugh D.G., Rupp G.P., Shull J.W. \& Field R.W. 1987. Detection of immunoglobulin G in the neonate. Journal of Equine Veterinary Science. 7(3): 124-129.

3 Carabetta D., Fernández D., Etcheverría A., Valle M. \& Padola N.L. 2016. Evaluación de la transferencia pasiva de la inmunidad en equinos mediante el uso de diferentes pruebas. InVet. 18(2): 333-340.

4 Clabough D.L., Levine J.F., Grant G.L. \& Conboy H.S. 1991. Factors associated with failure of passive transfer of colostral antibodies in Standardbred foals. Journal of Veterinary Internal Medicine. 5(6): 335-340.

5 Crisman M.V. \& Scarratt W.K. 2008. Immunodeficiency disorders in horses. Veterinary Clinics Equine Practice. 24: 299-310.

6 Davis R. \& Giguère S. 2005. Evaluation of five commercially available assays and measurement of serum total protein concentration via refractometry for the diagnosis of failure of passive transfer of immunity in foals. Journal of the American Veterinary Medical Association. 227(10): 1640-1645.

7 Erhard M.H., Luft C., Remler H.P. \& Stangassinger M. 2001. Assessment of colostral transfer and systemic availability of immunoglobulin $\mathrm{G}$ in new-born foals using a newly developed enzyme-linked immunosorbent assay (ELISA) system. Journal of Animal Physiology and Animal Nutrition. 85: 164-173.

8 Franz L.C., Landon J.C., Lopes L.A., Marinho L.A., Sarma C., Bruemmer J. \& Squires E.L. 1998. Oral and intravenous immunoglobulin therapy in neonatal foals. Journal of Equine Veterinary Science. 18(11): 742-748.

9 Giguère S. \& Polkes A.C. 2005. Immunologic disorders in neonatal foals. Veterinary Clinics Equine Practice. 21: 241-272.

10 Hofsaess F.R. 2001. Time of antibody absorption in neonatal foals. Journal of Equine Veterinary Science. 21(4): 158-159.

11 Jeffcott L.B. 1974. Some practical aspects of the transfer of passive immunity to newborn foals. Equine Veterinary Journal. 6(3): 109-115.

12 Kalinbacak A., Guzel M. \& Altintas I. 2005. Incidence of failure of immune passive transfer (FPT) in thoroughbred foals - Interest of a rapid diagnosis for FPT. Revue de Médecine Vétérinaire. 156(3): 163-165.

13 Kent J.E. \& Blackmore D.J. 1985. Measurement of $\operatorname{IgG}$ in equine blood by immunoturbidimetry and latex agglutination. Equine Veterinary Journal. 17(2): 125-129.

14 Kummer L.L., Govaere J. \& Egri B. 2018. Comparison of the reliability of snap foal Ig test, Gamma-Check E test, refractometry and electrophoresis for determining the immune status of newborn foals in the first hours of life. Acta Veterinaria Hungarica. 66(4): 573-586. 
15 Lang A., Souza M.V., Salcedo J.H.P., Sossai S., Araújo R.R., Lourenço G.G. \& Maia L. 2007. Imunidade passiva em eqüinos: comparação entre a concentração de IgG do soro materno, colostro e soro do neonato. Revista Ceres. 54(315): 405-411.

16 Le Blanc M.M. 2001. Update on passive transfer of immunoglobulins in the foal. Pferdeheilkunde. 17(6): 662-665.

17 LeBlanc M.M., Hurtgen J.P. \& Lyle S. 1990. A modified zinc sulfate turbidity test for the detection of immune status in newlyborn foals. Equine Veterinary Science. 10(1): 36-39.

18 McEwan A.D., Fisher E.W., Selman I.E. \& Penhale W.J. 1970. A turbidity test for the estimation of immune globulin levels in neonatal calf serum. Clinica Chimica Acta. 27: 155-163.

19 McGuire T.C., Crawford T.B., Hallowell A.L. \& Macomber L.E. 1977. Failure of colostral immunoglobulin transfer as an explanation for most infections and deaths of neonatal foals. Journal of the American Veterinary Medical Association. 170(11): 1302-1304.

20 McGuire T.C., Poppie M.J. \& Banks K.L. 1975. Hypogammaglobulinemia predisposing to infection in foals. Journal of American Veterinary Medical Association. 166(1): 71-75.

21 Morris D.D., Meirs D.A. \& Merryman G.S. 1985. Passive transfer failure in horses: incidence and causative factors on a breeding farm. American Journal of Veterinary Research. 46(11): 2294-2299.

22 Perkins G.A. \& Wagner B. 2015. The development of equine immunity: Current knowledge on immunology in the young horse. Equine Veterinary Journal. 47: 267-274.

23 Raidal S.L. 1996. The incidence and consequences of failure of passive transfer of immunity on a Thoroughbred breeding farm. Australian Veterinary Journal. 73(6): 201-206.

24 Raidal S.L, McTaggart C. \& Penhale J. 2005. Effect of withholding macromolecules on the duration of intestinal permeability to colostral IgG in foals. Australian Veterinary Journal. 83(1-2): 78-81.

25 Riley C.B., McClure J.T., Low-Ying S. \& Shaw R.A. 2007. Use of fourier-transform infrared spectroscopy for the diagnosis of failure of transfer of passive immunity and measurement of immunoglobulin concentrations in horses. Journal of Veterinary Internal Medicine. 21: 828-834.

26 Rumbaugh G.E., Ardans A.A., Ginno D. \& Trommershausen-Smith A. 1978. Measurement of neonatal equine immunoglobulins for assessment of colostral immunoglobulin transfer: comparison of single radial immunodiffusion with zinc sulfate turbidity test, serum electrophoresis, refractometry for total serum protein, and the sodium sulfite precipitation test. Journal of American Veterinary Medical Association. 172(3): 321-325.

27 Rumbaugh G.E., Ardans A.A., Ginno D. \& Trommershausen-Smith A. 1979. Identification and treatment of colostrum-deficient foals. Journal of American Veterinary Medical Association. 174(3): 273-276.

28 Sedlinská M., Krejcí J. \& Vyskocil M. 2005. Evaluation of field methods for determining immunoglobulins in sucking foals. Acta Veterinaria Brno. 74: 51-58.

29 Silva C.A.M., Rubin M.I.B., Waihrich F.L. \& Pelegrini J.L.M. 1984. Diagnóstico da imunidade passiva adotiva adquirida através do colostro no potro recém-nascido. Pesquisa Veterinária Brasileira. 4(1): 11-15.

30 Silva C.A.M., Silva J.F.S., Alda J.L., Silva J.H.S. \& Rubin M.I.B. 1988. Diagnóstico imediato da imunodeficiência do potro recém-nascido. Revista Brasileira de Reprodução Animal. 12(4): 203-212.

31 Sprayberry K.A. 2003. Neonatal transfusion medicine: the use of blood, plasma, oxygen-carrying solutions, and adjunctive therapies in foals. Clinical Techniques in Equine Practice. 2(1): 31-41.

32 Tallmadge R.L., McLaughlin K., Secor E., Ruano D., Matychak M.B. \& Flaminio J.B.F. 2009. Expression of essential B cell genes and immunoglobulin isotypes suggests active development and gene recombination during equine gestation. Developmental and Comparative Immunology. 33: 1027-1038.

33 Tallmadge R.L., Miller S.C., Parry S.A. \& Felippe M.J.B. 2017. Antigen-specific immunoglobulin variable region sequencing measures humoral immune response to vaccination in the equine neonate. PLoS One. 12(5): e177831.

34 Tyler-McGowan C.M., Hodcson J.L. \& Hodgson D.R. 1997. Failure of passive transfer in foals: incidence and outcome on four studs in New South Wales. Australian Veterinary Journal. 75(1): 56-59.

35 Young K.M. \& Lunn D.P. 2000. Immunodiagnostic testing in horses. Veterinary Clinics of North America: Equine Practice. 16: 79-103. 